\title{
Чэнь Шэннань
}

Санкт-Петербургский государственный университет,

Россия, 199034, Санкт-Петербург, Университетская наб., 7-9

727852429@qq.com

\section{О первом переводе книги «Сань цзы цзин» на русский язык}

Для цитирования: Чэнь Шэннань. О первом переводе книги «Сань цзы цзин» на русский язык. Вестник Санкт-Петербургского университета. Язык и литература. 2019, 16 (2): 320-332. https://doi.org/10.21638/spbu09.2019.211

«Сань цзы цзин», или «Троесловный канон», — это книга, с которой начиналось школьное обучение в Древнем Китае на протяжении сотен лет. В ней содержатся базовые знания о китайской культуре, философии, географии, образовании, истории и т. п. Она написана в ритмизованной прозе: каждая строка состоит из трех иероглифов, и каждые четыре строки образуют строфу. Книга «Сань цзы цзин» также являлась важным учебным материалом по китайскому языку для иностранных миссионеров, приезжавших в Китай с XVI в. В настоящей статье впервые сравниваются два русских перевода книги «Сань цзы цзин», которые содержатся в двух рукописях, хранящихся в Отделе рукописей Библиотеки Академии наук: «Сань дзы гинъ или нравоучителных речей трисловная книга» (БАН.17.5.22) и «Китайская книга Сан дзы гин, то есть трисловное нравоучение, содержащее в себе краткую историю» (БАН.17.16.19). Упомянутые рукописи были приписаны ученику второй Российской духовной миссии И.К. Россохину (1717-1761) в работах В.П. Тарановича и П.Е. Скачкова. Сравнение двух переводов показало, что текст в рукописи БАН.17.16.19 был переведен самим И.К. Россохиным, тогда как «Сань дзы гинъ» в списке БАН.17.5.22 был переведен другим человеком, видимо, в Петровское время: об этом свидетельствуют характерные для того времени особенности орфографии, лексики и грамматики. Кроме того, у переводов было разное назначение: перевод И.К. Россохина содержал объяснения и был нацелен на обучение китайскому и маньчжурскому языкам, тогда как другой был выполнен пословно и не имел дидактических целей.

Ключевые слова: Иларион Россохин, Сань изы изин, русские переводы XVIII века.

\section{Введение}

«Сань цзы цзин», или «Троесловный канон», - это книга, с которой начиналось школьное обучение в Древнем Китае на протяжении сотен лет. Большинство ученых считают, что она была создана во время династии Южной Сун (1127-1279), но до сих пор этот вопрос не решен окончательно [Ли 2004: 156]. В книге содержатся базовые знания о китайской культуре, философии, истории, образовании, моральных правилах и географии. «Сань цзы цзин» написана ритмизованной прозой: каждая строка состоит из трех иероглифов, и каждые четыре строки образуют строфу. Благодаря этому книга очень удобна для изучения иероглифов и овладе-

() Санкт-Петербургский государственный университет, 2019 
ния базовыми знаниями китайского языка и культуры. По этой причине «Сань цзы цзин» стала одним из главных учебников для начального этапа школьного образования, ее заучивали наизусть [Чжао 2015: 132].

В течение нескольких сотен лет при сохранении троесловной структуры текста содержание в разные времена редактировалось и обновлялось, в связи с чем до нас дошли несколько версий книги, отличающихся между собой, в основном, объемом текста (1044, 1050, 1056, 1068 и 1086 иероглифов) и сведениями об истории [Ли 2008: 125-129].

Начиная с XVI в. в Китай приезжали миссионеры из западных стран, а в начале XVIII в. начали приезжать миссионеры из России. Книга «Сань цзы цзин» их заинтересовала, они использовали ее для изучения китайского языка и перевели на разные иностранные языки. Первым был перевод на латинский язык, который выполнил в конце XVI в. миссионер из Италии Ло Минцзянь (Микеле Руджели, 1543-1607) [Чжао 2015: 133]. После него появились и переводы на другие языки: на английский, немецкий и русский.

Несмотря на то что книга «Сань цзы цзин» привлекла к себе широкое внимание как в Китае, так и в России, тема ее переводов на иностранные языки еще недостаточно изучена. Китайские ученые большее внимание уделяют вопросам об авторе «Сань цзы цзин», о ее разных версиях, языковых особенностях и о ее вкладе в начальное образование. В последние годы возрос интерес к изучению ее переводов, особенно после того, как в 2014 г. был опубликован новый английский перевод «Сань цзы цзин» [Чжао 2014], который вызвал бурные дискуссии в среде филологов. В 2012 г. был опубликован новый русский перевод «Сань цзы цзин», сделанный Ю. М. Галеновичим [Галенович 2012], однако он не вызвал такого горячего обсуждения, как английский перевод.

В России о книге «Сань цзы цзин» даются лишь общие сведения. Например, в пятитомном издании «Духовая культура Китая: энциклопедия» имеется статья «Сань цзы цзин», написанная А.И. Кобзевым [Кобзев 2009: 825-828]. Статья В.Б. Югая «Феномен “Сань цзы цзина” посвящена содержанию, композиции и влиянию книги «Сань цзы цзин» на педагогическую литературу. Что касается ее русских переводов, то они не привлекали внимания китайских ученых [Югай 2006: 138-144]. Переводы на русский язык упомянуты только в работах, посвященных достижениям иностранных миссионеров в Китае и обзору вопроса о переводе «Сань цзы цзин» на иностранные языки. Более ранним переводам уделяют внимание лишь некоторые ученые, такие так В.П. Таранович и П.Е. Скачков, которые составляли реестр неопубликованных рукописей И.К. Россохина, а также Чжан Хунъянь, автор статьи, посвященной истории переводов «Сань цзы цзин» и их распространению в России [Чжан 2018: 93-98].

Тем не менее, несмотря на то что перечисление русских переводов обычно начинается с перевода И. К. Россохина, существует иной перевод, о котором идет речь в настоящей статье. Он упомянут в статье, посвященной распространению «Сань цзы цзин» в России [У 2007: 111], но не исследован. В задачу данной статьи входит сравнение и лингвистическое описание двух древнейших переводов, которые были атрибутированы И. К. Россохиным.

Самые ранние рукописи с русским переводом книги «Сань цзы цзин», как было упомянуто выше, были приписаны Илариону Калиновичу Россохину в рабо- 
тах В.П.Тарановича и П.Е.Скачкова, но его перевод остался в рукописи и не был издан. Впоследствии книга «Сань цзы цзин» неоднократно переводилась: были изданы переводы А. Л. Леонтьева (ученика четвертой Российской духовной миссии) и Н. Я. Бичурина (главы девятой Российской духовной миссии в Пекине) [Цай 2006: 95-96].

И. К. Россохин был учеником второй Российской духовной миссии в Пекине. В 1725 г. он был принят в Монгольскую школу при Иркутском Вознесенском монастыре. После трех лет обучения в 1729 г. он с двумя товарищами по школе был отправлен в Китай. В 1729-1741 гг. он учил китайский и маньчжурский языки в Пекине, много работал и добился больших успехов в их изучении. В 1735 г. по просьбе Лифаньюаня (Палаты по делам инородцев при императорском дворе) он был зачислен переводчиком в Лифаньюань и преподавателем в школу русского языка при Дворцовой канцелярии, где обучал маньчжуров и китайцев. В 1741 г. он вернулся в Россию и был направлен Коллегией иностранных дел в распоряжение Академии наук для переводов и обучению китайскому и маньчжурскому языкам, здесь обучал четырех учеников. Его школа китайского и маньчжурского языков существовала десять лет, до 1751 г.

В Древнем Китае на первом году обучения школьники были обязаны заучивать наизусть «Сань цзы цзин», а затем переходили к зазубриванию другого старинного текста — «Бай цзя син» («Фамилии ста семей»), написанного в Х в., т.е. на триста лет раньше, чем «Сань цзы цзин». Это зарифмованный список часто встречающихся китайских фамилий. После этого ученики приступали к заучиванию «Цянь цзы вэнь» («Тысячесловие»). Этот текст был написан в VI в. и состоит из тысячи иероглифов, которые разбиты на 250 строк - по четыре иероглифа в строке. Вышеперечисленные три книги вместе называются «Сань - Бай - Цянь» («Три - Сто Тысяча») [Сидихменов 2010: 476-477]. Только после «Сань - Бай - Цянь» можно начать изучать «Сышу» («Четверокнижие»), избранный Чжу Си (1130-1200) свод канонических конфуцианских текстов, состоящий из четырех книг: «Да сюэ», «Чжун юн», «Лунь юй» и «Мэн цзы». Настоящая традиция сохранилась в Китае вплоть до XIX в. И.К. Россохин следовал этим традиционным методам первоначального образования в своей школе китайского и маньчжурского языков. Ученики заучивали наизусть классические тексты, такие как «Сань цзы цзин», «Цянь цзы вэнь», «Сышу» [Скачков 1977: 44].

В Отделе рукописей Библиотеки Академии наук в Санкт-Петербурге (БАН) хранятся две рукописи, в которых представлен перевод книги «Сань цзы цзин». Обе рукописи поступили в библиотеку в 1744 г. [Мурзанова, Бобров, Петров 1956: 225]:

1. БАН.17.5.22. «Сань дзы гинъ или нравоучителных речей трисловная книга» (далее - рукопись A). Рукопись состоит из 28 листов. Рукопись датирована П.Е. Скачковым 1730 г. [Скачков 1977: 393], а В. П. Тарановичем - серединой XVIII в. [Таранович 1945: 235]. На л. 1 написано название книги «Сань дзы гинъ или нравоучителных речей трисловная книга», на листах 2-27 читается сам перевод, л. 28 пустой. Никаких авторских или владельческих записей в рукописи не содержится.

2. БАН.17.16.19. «Китайская книга Сан дзы гин, то есть трисловное нравоучение, содержащее в себе краткую историю» (далее - рукопись Б). Рукопись не датирована, состоит из 46 листов. В ней представлены тексты на трех языках - на маньчжурском, китайском и русском. В конце китайского текста, на л. 46, на китай- 
ском языке написано «罗锁馨翻», что означает «перевел Россохин». На основании этой записи можно определить, что перевод именно этой рукописи был выполнен И.К. Россохиным.

П.Е.Скачков в своей книге о китаеведении в России перечислил все известные рукописи И.К. Россохина. Из 34 рукописей 11 им были выделены как рукописи-автографы [Скачков 1977: 389-395]. Необходимо обратить внимание на то, что большинство этих рукописей-автографов написано в 1741-1751 гг., во время работы школы китайского и маньчжурского языков. Поэтому в написании некоторых из этих рукописей могли участвовать ученики И. К. Россохина. Об этом свидетельствуют списки «Китайского графа Сюэ-вынь цин-гуна собственные рассуждения о себе самом» ${ }^{1}$ и «О двадцати четырех пунктах, касающихся до родительского почтения» ${ }^{2}$, в которых после русского перевода имеется автограф И.К. Россохина, после китайского - «по китайски писал ученик Яков Волков», а после маньчжурского - «по манджурски писал ученик Степан Чекмарев». Не во всех рукописяхавтографах, на наш взгляд, тексты написаны самим И. К. Россохиным, потому что почерки этих списков и автографа часто отличаются. Для отождествления почерка И.К. Россохина надежнее рассматривать почерки рукописей-автографов, написанных до открытия школы - во время его пребывания в Пекине. В число таких рукописей входят «С которого году манджурские ханы начали писатца ханами, где прежде государствовали, сколка было всех ханов, как называютца и сколко лет которой хан государствовал» ${ }^{3}$, написанная в 1736 г., «Обстоятельное описание о происхождении и состоянии манджурского народа и войска, в осмии знаменах состоящего ${ }^{4}$, написанная в 1739 г., а также «Собрание важнейших извлечений, переведенных с русского языка» ${ }^{5}$, хранящаяся в Институте восточных рукописей РАН. Известны также почерки ученика И. К. Россохина Якова Волкова по рукописи «Книга Сышу или шанъ Лунь июу» ${ }^{6}$, в которой имеется автограф Якова Волкова. Сравнение почерков в рукописях $A$ и Б с почерками в вышеупомянутых рукописях показывает, что в рукописях $A$ и Б почерки другие и не принадлежат ни И.К. Россохину, ни Якову Волкову ${ }^{7}$

Сопоставление текстов в рукописях $A$ и $Б$ показало, что перед нами разные переводы книги «Сань цзы цзин». Между ними существует немало различий как в структуре текста, так и в технике перевода.

\section{1. Структура текста в рукописях $A$ и $Б$}

В рукописи $A$ представлен только текст на русском языке, а в $D-$ тексты на трех языках: на одной стороне листа расположены тексты на маньчжурском и китайском языках, а на обороте листа - текст на русском. В китайском и маньчжурском текстах строки пронумерованы: их 356. Стоит упомянуть, что на листах 1-14

${ }^{1}$ БАН. 34.5.11.

2 Архив РАН. Разр. II. Оп. 1. № 116.

3 Архив РАН. Разр. IV. Оп. 1. № 244.

${ }^{4}$ Там же. № 322.

${ }^{5}$ Из предисловия рукописи узнаем, что первые десять тетрадей написаны Россохиным.

${ }^{6}$ БАН. 16.9.21.

7 Выражаем благодарность сотруднику Отдела рукописей Библиотеки Академии наук И. А. Вознесенской за помощь и консультацию по данному вопросу. 
рядом с маньчжурскими буквами и китайскими иероглифами дается еще их транскрипция русскими буквами, например: 人 жинь «человек», 之 джы «служебное слово, отделяющее предшествующее определение от последующего определяемого слова», 初 чy «начало» и др. Это дает нам повод предполагать, что именно Б служила учебником в преподавании языков. Кроме того, в рукописи 5 , в разделе об истории Китая (л. 23-34), на левом поле страницы даются примечания с помощью знаков «\#» (л. 23 об. и л. 24 об.) и «*» (л. 24 об. - л. 33 об.), поставленных над словами в основном тексте. В примечаниях указаны годы исторического периода или события, например:

Таутанской за ихъ снисхождение и великую кротость отъ всего ученого свету названо золотымъ векомъ. А потомъ наступившихъ хановъ хяского: июу вана ускихъ вынъ ванна, и увана ${ }^{* *}$ именовали тремя ванами (л. 24 об. - л. 25).

Примечания на полях: Лета прежде рождества Христова."2357.. \#\#2255.. *2205.. ${ }^{* \star} 1766$. $* * * 1122$.

Трехъязычная структура свойственна не только этой рукописи И.К. Россохина, но и другим четырем его рукописям, таким как «О дватцати четырехъ пунктахъ, касающихся дородительского почтения» ${ }^{8}$, Школьныя простыя манджурского и китайского языков разговоры» ${ }^{9}$, «итайского графа Сюэ-вынь цин-гуна собственные рассуждения о себе самом» ${ }^{10}$ и «Китайского хана и принцов его титулы и достоинства» ${ }^{11}$. Схожие примечания найдены и в других рукописях круга И.К. Россохина, которые также были учебными пособиями для учеников, например в «Цянь-дзы-вынь, то есть учение с краткою историей из тысячи китайских разных характеров» ${ }^{12}$, который тоже был учебным пособием [Скачков 1977: 44]. Это свидетельствует о том, что при обучении языкам И. К. Россохин уделял внимание не только чтению текстов, но и изучению важных фактов истории и культуры Китая.

\section{2. Техника перевода в рукописях $A$ и $Б$}

\section{1. Способы перевода}

В рукописи $A$ представлен перевод, в котором наблюдается попытка сохранить простоту текста оригинала. Перевод выполнен построчно без объединения или изменения порядка строк. В рукописи Б внесены изменения: кое-где добавлены союзы, которых нет в китайском оригинале, где-то изменен порядок строк. Это более подробный перевод с объяснениями и комментариями (табл. 1) (орфография рукописей полностью сохраняется).

Приведенный пример показывает, что в рукописи $A$ перевод выполнен построчно. Например, в переводе строки 养不教, 父之过. 养 означают «содержать,

\footnotetext{
${ }^{8}$ Архив РАН. Разр. II. Оп. 1. № 116.

9 БАН. 32.6.17.

${ }^{10}$ БАН. 34.5.11.

11 Архив РАН. Разр. II. Оп. 1. № 119.

12 Архив РАН. Разр. II. Оп. 1. № 115.
} 
Таблица 1. Способы перевода в рукописях $\boldsymbol{A}$ и $\boldsymbol{Б}$

\begin{tabular}{|c|c|c|}
\hline По-китайски & Рукопись $A$ & Рукопись $Б$ \\
\hline $\begin{array}{l}\text { 养不教 } \\
\text { 父之过 } \\
\text { 教不严 } \\
\text { 师之惰 }\end{array}$ & $\begin{array}{l}\text { Воспитовать анешбучать } \\
\text { Wтеческое есть погрьшение } \\
\text { Wбучать анекрьпко содьржать } \\
\text { Учителская есть льность }\end{array}$ & $\begin{array}{l}\text { Отеческое есть погрбшенїе ежели онъ своихъ } \\
\text { дътей воспитывать будетъ без добраго ученїя. } \\
\text { Ато называется несмотренїе учителское, } \\
\text { когда онъ обучая своихъ учениковъ, крђпко } \\
\text { содержать ихъ небудетъ. }\end{array}$ \\
\hline
\end{tabular}

кормить», 不 - «не», 教 - «обучать», 父 - «отец», 之 - «служебное слово, отделяющее предшествующее определение от последующего определяемого слова», 过 — «вина, ошибка, грех».

В рукописи $Б$ изменен порядок строк - перевод второй строки предшествует переводу первой строки, перевод четвертой строки - переводу третьей строки. Добавлены и союзы ежели, а то, когда, чтобы связь между строками стала более тесной.

Стоит отметить, что в русском переводе, представленном в рукописи $Б$, почти в каждой строфе наблюдается объединение двух или нескольких строк в одну или изменение порядка строк. Это показывает, что в ходе перевода автор не руководствовался построчным принципом, а уделял больше внимания объяснению смысла текста оригинала.

\section{2. Перевод имен собственных}

В оригинале много имен собственных, которые остались бы непонятными без объяснения. В обоих рукописях большинство имен существительных передается с помощью транскрипции, но в Б иногда к транскрипции добавляются объяснения. Примеры приведены в табл. 2.

Таблица 2. Перевод имен собственных в рукописях $\boldsymbol{A}$ и $\boldsymbol{B}$

\begin{tabular}{|c|c|c|}
\hline По-китайски & Рукопись $A$ & Рукопись 5 \\
\hline 羲农 & фухи и шынь нунъ & первоначальные ханы фухи и шынь нунъ \\
\hline 黄帝 & хуанъ ди & царь хуанъ ди \\
\hline 纣 & Джуу царь & последний шанский хань называемый Джыусинь \\
\hline 唐高祖 & танской царь Гао дзу & первый танской хань Гау дзу \\
\hline 王莽 & Ванъ Ман & министръ Ванъ Манъ \\
\hline
\end{tabular}

Вышеприведенные примеры показывают, что в рукописи 5 , кроме транскрипции имен человека, добавлены титулы, такие как первоначальные ханы, изарь, nоследний шанский изарь, первый танской хань, министръ. С помощью комментариев объясняется, о каких людях идет речь. 


\section{3. Качество перевода}

В обеих рукописях встречаются неточные переводы, но ошибки в них не повторяются; это значит, что переводы делались изолированно друг от друга. Примеры приведены в табл. 3.

Таблиия 3. Неточные переводы в рукописях $\boldsymbol{A}$ и $\boldsymbol{Б}$

\begin{tabular}{|l|l|l|}
\hline По-китайски & \multicolumn{1}{|c|}{ Рукопись $A$} & \multicolumn{1}{|c|}{ Рукопись 5} \\
\hline $\begin{array}{l}\text { 子不学 } \\
\text { 断机杼 }\end{array}$ & $\begin{array}{l}\text { Для необучения сыновнего } \\
\text { Фабрику свою бросила }\end{array}$ & $\begin{array}{l}\text { а что ея детя безучения пребывали. То она } \\
\text { иткать перестала }\end{array}$ \\
\hline 梁灭之 & Икакъже пало лянское царство & $\begin{array}{l}\text { А наконъцъ ханами фамилїи хыу-лянъ } \\
\text { уничтожена }\end{array}$ \\
\hline $\begin{array}{l}\text { 人遗子 } \\
\text { 金满篔 }\end{array}$ & $\begin{array}{l}\text { Иныхъ людеи детям оставляется } \\
\text { Полнои сундук злата }\end{array}$ & $\begin{array}{l}\text { но я чужимъ детямъ отьдаю во владение } \\
\text { полной сундукъ злата. }\end{array}$ \\
\hline
\end{tabular}

Первый пример - это рассказ о матери, которая занималась прядением и ткачеством. Увидев, что сын перестал учиться, мать взяла нож и перерезала ткань. Учебу сына она сравнивала с ткачеством, потому что и учеба, и ткачество требуют прилежной работы для достижения успехов. В рукописи $A$ китайское слово 机杼 со значением 'ткацкий станок' переведено словом бабрика, в рукописи $Б$ - перевод более точный.

Во втором примере речь идет о завершении династии Тан (618-907) и замене ее новой династией - династией Хоу Лян (Поздний Лян, 907-923). В переводе $A$ допущен неправильный перевод этой строки. Автор, видимо, плохо знал историю Китая и вместо «Тан» написал «Лян». Также нужно отметить, что автор не обращал внимания на различие между династиями Лян (502-557) и Поздний Лян (по-китайски Хоу Лян, 907-923). В приведенном контексте речь идет о династии Поздний Лян (Хоу Лян). Та же самая строка в переводе Б переведена правильно - «хыу-лянъ».

А в последнем примере значение строк таково: другие люди оставляют своим детям полный сундук золота. 人 означает 'иной, другой', 遗 — 'оставить', 子 - ‘дети', 金 — ‘золото, 满 — ‘полный', 篭 — 'емкость для хранения ценностей.' Но в рукописи Б вместо 'других' объясняется как 'я чужим детям отдаю'. Это неточный перевод.

Сравнение техники перевода показывает, что в рукописи $A$ представлен построчный перевод, а в рукописи $5-$ объяснительный перевод. В обеих рукописях встречаются неточные переводы, но эти ошибки не совпадают. Расхождение в понимании одной и той же строки в двух рукописях показывает, что переводы в них могли быть выполнены разными людьми.

Кроме того, в двух рукописях очень часто для перевода одного и того же китайского слова использованы разные русские слова (табл. 4).

Лексические варианты в некоторых парах отличаются происхождением. Так, слово пес имеет церковнославянское происхождение, а слово собака - русское $^{13}$. В определенном контексте разные варианты являются синонимами, например на-

${ }^{13}$ Словарь Академии Российской (ч. IV, стб. 783) снабжает слово «пес» пометой «Сл.» (Словарь Академии Российской. СПб.: Императорская Академия Наук, 1789-1794). 
Таблица 4. Разные переводы одного и того же китайского слова в рукописях $\boldsymbol{A}$ и $\boldsymbol{B}$

\begin{tabular}{|c|c|c|}
\hline По-китайски & Рукопись $A$ & Рукопись 5 \\
\hline 性本善 & Натурою благъ & Природа съ которою человекъ родился \\
\hline 师之惰 & Учителская есть льность & А то называется несмотрение учителское \\
\hline 不知义 & Истины неразумъетъ & ни слова не разумеетъ \\
\hline 知某数 & Всякое число знаите & Знай счотъ \\
\hline $\begin{array}{l}\text { 三光者 } \\
\text { 日月星 }\end{array}$ & 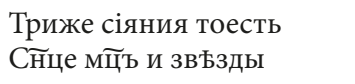 & Три светила суть солнце луна и звезды. \\
\hline 鸡犬豕 & Курицыже пси и свиньи & курицы собаки и свинья \\
\hline 二十篇 & Двадесять статей & В дватцати главахъ \\
\hline
\end{tabular}

тура и природа в значении «врожденный характер и качества человека». Стоит отметить, что слово натура является относительно новым заимствованным словом из латинского языка через польский, которое впервые встречается в посланиях A. Курбского в XVI в. ${ }^{14}$ Синонимичными являются также учителская леность и несмотрение учителское в значении 'нестрогий подход учителя к ученикам в обучении'. Иногда разные варианты отражают расхождение в понимании текста в авторов: например, 义 в значении 'мораль, нравственность' в рукописи $A$ переведено словом истина, а рукописи $Б$ - слово, ни то ни другое не точно. Слово 篇 в значении 'часть книги, раздела, главы' в рукописи $A$ переведено словом статья, а в рукописи $5-2 л а в а$, в этом случае перевод в $Б$ оказывается правильнее.

Вышеперечисленные различия в переводе одного и того же слова дают нам повод предположить, что переводы в двух рукописях выполнены разными людьми. При этом в первом переводе употребляется больше церковнославянизмов и новых заимствований.

\section{3. Орфография рукописей $A$ и $Б$}

В обеих рукописях орфография не упорядочена, что вообще характерно для письменности XVIII в. Довольно свободно ставятся $b$ и $z$ после $u$; употребляются

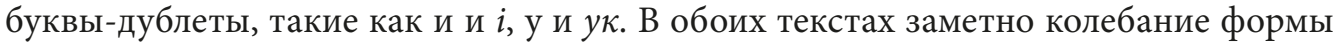
прилагательного в им. п. мн. ч. на -ыя $u$-ые.

Тем не менее между рукописями $A$ и Б есть принципиальные различия. Первое заключается в употреблении титла. Необходимо отметить, что титла были устранены в результате Петровской реформы азбуки и введения гражданского шрифта 1708-1710 гг. [Григорьева 2004: 8]. В рукописи $A$ некоторые слова регулярно пишут-

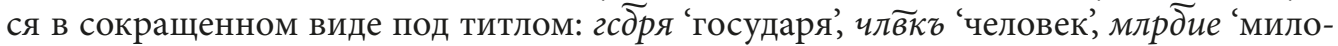

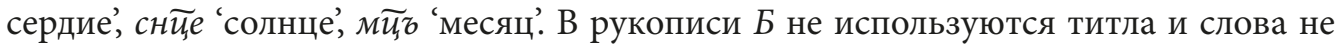
пишутся в сокращенном виде.

${ }^{14}$ Преображенский А.Г. Этимологический словарь русского языка. Т. 1. М.: Тип. Г.Лисснера и Д. Собко, 1910-1914. С. 595. 
Второе отличие заключается в том, что в рукописи $A$ активно используются буквы, которые не пишутся в Б, такие как омега «w» $и$ лигатура «ш̋». Например,

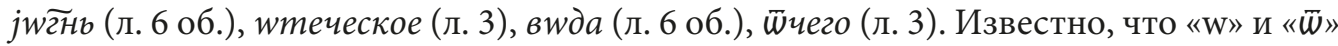
были исключены из азбуки Петром I как «лишние» буквы [Григорьева 2004].

Из вышесказанного можно сделать вывод, что в рукописи $A$ более архаичная орфография, предшествующая более новой орфографии в рукописи $Б$.

\section{4. Славянизмы в переводах в рукописях $A$ и $Б$}

В обеих рукописях встречаются славянизмы, но в рукописи $A$ их больше, чем в рукописи $Б$. Это отражено на разных языковых уровнях.

\section{1. На фонетическом уровне}

В рукописи А встречаются неполногласные формы, как всамои младостп (л. 4), древоже злато (л. 6 об.), восемь гласов (л. 8), власами (л. 22) и др. Они соответствуют следующим словам в рукописи 5 в полногласных формах: в самыхъ молодыхъ летахъ, дерево камень золото, восемь голосов, волосы.

В рукописи $A$ некоторые слова представлены в церковнославянской форме. Например, учениць вместо «ученики», вецех вместо «веках», нощьь вместо «ночь» и др. Здесь отражаются рефлексы второй палатализации, церковнославянских рефлексов $t j$, что говорит об ориентации переводчика на церковнославянскую норму. В рукописи $Б$ подобных форм не встречается.

\section{2. На морфологическом уровне}

В рукописи $A$ имеются более архаичные формы глаголов, такие как аорист: $\mathrm{Ha}$ писася, приведе, нарече, начася и сетовах. В рукописи Б для выражения прошедшего времени регулярно использован перфект без связки: написал, привели, назвал, начались и каялся (табл. 5).

Кроме этого в рукописи $A$ встречаются инфинитивы как на $-m b$, так и на -mu, например: А сыну ежели неучитися (л. 3 об.); Могут начинатись учить (л. 11 об.); Аще же небудете обучатися (л. 25 об.); Человекъ небудеть учитися (л. 26). В рукописи 5 - только инфинитивы глаголов на -mb.

Отличие между переводами заключается в употреблении форм возвратных глаголов на -ся. В рукописи $A$ употребляются как формы на - $c b$, так и формы на -cя, например продолжалася (л. 16 об.), продолжалась (л. 17). В рукописи Б форм на -ся не содержится.

Необходимо отметить, что употребление аориста, форм инфинитива на -mu и форм возвратных глаголов на -ся было свойственно в XVIII в. только Петровскому времени, когда инерция в употреблении церковнославянизмов была еще очень велика [Круглов 2004: 29]. В Петровское время вышеупомянутые элементы считались «признаками книжности», затем они постепенно устранялись: формы аориста заменялись формами простого прошедшего времени (л-формами без связки), формы инфинитива на -mu - на формы с $-m b$, а окончание форм возвратных глаголов после гласного звука - на -сь [Живов 1996: 99]. Указанные особенности встречают- 
Таблица 5. Славянизмы на морфологическом уровне в рукописях $\boldsymbol{A}$ и $\boldsymbol{B}$

\begin{tabular}{|l|l|l|}
\hline По-китайски & \multicolumn{1}{|c|}{ Рукопись $A$} & \multicolumn{1}{|c|}{ Рукопись 5} \\
\hline $\begin{array}{l}\text { 作中庸 } \\
\text { 孔伋 }\end{array}$ & $\begin{array}{l}\text { Джунъ юнъ книга написася Кунъ } \\
\text { Тиемъ (л. 10) }\end{array}$ & $\begin{array}{l}\text { Книгу Джунъ юнъ называемую написал Кунъ } \\
\text { Ги (л. 16 об.) }\end{array}$ \\
\hline 礼乐备 & $\begin{array}{l}\text { политика пение и музыка } \\
\text { в совершенство приведе (л. 10 об.) }\end{array}$ & $\begin{array}{l}\text { Политику съ музыкою привели въ } \\
\text { совершенство (л. 20 об.) }\end{array}$ \\
\hline $\begin{array}{l}\text { 汤伐夏 } \\
\text { 国号商 }\end{array}$ & $\begin{array}{l}\text { Тан царь завоевал Ся царство, } \\
\text { И нарече титлу своему царству } \\
\text { шанъ (л. 16) }\end{array}$ & $\begin{array}{l}\text { Ханъ Чынъ танъ, уничтоживши Хяскую, } \\
\text { назвалъ свое правителство Шанъ (л. 25 об.) }\end{array}$ \\
\hline $\begin{array}{l}\text { 始春秋 } \\
\text { 终战国 }\end{array}$ & $\begin{array}{l}\text { Начася от времянии чунь циу, до } \\
\text { последняго времяни джань гуэ } \\
\text { (л. 16 об.) }\end{array}$ & $\begin{array}{l}\text { Сие замешателство началось отъ времени } \\
\text { Чунциу и продолжалось по самой конецъ } \\
\text { времени Джань-гуэ (л. 27 об.) }\end{array}$ \\
\hline $\begin{array}{l}\text { 彼既老 } \\
\text { 犹悔迟 }\end{array}$ & $\begin{array}{l}\text { Когда ж состарелся, то сетовах } \\
\text { о томъ что опоздалъ (л. 23) }\end{array}$ & $\begin{array}{l}\text { А какъ онъ пришолъ въ глубокую старость, } \\
\text { то каяся о томъ что онъ время упустилъ } \\
\text { (л. 38 об.) }\end{array}$ \\
\hline
\end{tabular}

ся в рукописи $A$, но не доминируют, в рукописи 5 отсутствуют полностью. На основании этого также можно предположить, что перевод рукописи $A$ был выполнен в Петровское время.

\section{3. На лексическом уровне}

В рукописи $A$ использованы слова, зафиксированные в «Словаре русского языка XVIII века» как славянизмы, например: древле ${ }^{15}$, брашно $^{16}$, благоговюиность ${ }^{17}$, лепоствуеть ${ }^{18}$, петельь $^{19}$, аще $^{20}$ и др.

В рукописи $Б$ вышеперечисленные слова соответствуют следующим словам и словосочетаниям: въ древние времени, пропитание, благочестие, надлежит, пеmухи, когда, которые в указанном словаре не зафиксированы как славянизмы.

\section{Выводы}

Все вышесказанное привело нас к выводу, что переводы в рукописях $A$ и $D$ выполнены разными людьми и в разное время. В рукописи $A$ представлен построчный перевод, тогда как в Б содержится объяснительный перевод. В рукописи $A$ язык более архаичный, а в рукописи $Б$ автор сознательно отказывается от славянизмов и стремится объяснить текст простым и близким к бытовой речи языком. Язык перевода в рукописи $A$ по стилю и технике перевода тяготеет к нормам Пе-

15 Сл. РЯ XVIII снабжает слово «древле» пометой «Слав.» (Словарь русского языка XVIII века. Сорокина Ю. С. (ред.). Л.: Наука, 1984-1991. Вып. 6. С. 254-255).

${ }^{16}$ Сл. РЯ XVIII снабжает слово «брашно» пометой «Слав.» (Указ. соч. Вып. 2. С. 133-134).

17 Сл. РЯ XVIII снабжает слово «благовейный» пометой «Слав.» (Указ. соч. Вып. 2. С. 35).

18 Сл. РЯ XVIII снабжает слово «лепоствовать» пометой «Слав.» (Указ. соч. Вып. 11. С. 154).

${ }^{19}$ Сл. РЯ XVIII снабжает слово «петел» пометой «Слав.» (Указ. соч. Вып. 19. С. 186).

${ }^{20}$ Сл. РЯ XVIII снабжает слово «аще» пометой «Слав.» (Указ. соч. Вып. 1. С. 120-121). 
тровского времени. Можно предположить, что перевод в рукописи $A$ сделан раньше, чем перевод в рукописи $Б$, и он был выполнен в начале XVIII в. Этот текст мог быть у И.К. Россохина как образец более раннего перевода, который достался ему от прежних русских миссионеров в Китае. Перевод И.К. Россохина представлен в рукописи $Б$, именно он служил одним из учебников для обучения китайскому и маньчжурскому языкам.

Вопрос о том, кто автор рукописи $A$, остается нерешенным. Но известно, что И.К. Россохин был учеником Второй Российской духовной миссии в Пекине. Первая Российская духовная миссия была учреждена в 1713 г. Святейшим Синодом Русской православной церкви, но сведений о ее членах осталось мало, и до сих пор ничего не известно об их конкретных переводах. Некоторые из членов первой миссии прожили в Пекине более 20 лет и там умерли [Скачков 1977: 37]. За эти годы они вполне могли изучить китайский и маньчжурский языки и приобрести навыки перевода. Это позволяет нам высказать гипотезу, что текст «Сань цзы цзин», сохранившийся в рукописи $A$, был переведен во время работы Первой Российской духовной миссии в Пекине.

\section{Литература}

Галенович 2012 - Троесловие (Сань-изы-изин). Пер. с кит. Галенович Ю. М. (перев., ред.). М.: СПСЛ, Русская панорама, 2012. 296 с.

Григорьева 2004 - Григорьева Т.М. Три века русской орфографби (XVIII-XX вв.). М.: Элпис, 2004. $456 \mathrm{c}$.

Живов 1996 - Живов В. М. Язык и культура в России XVIII века. М.: Языки русской культуры, 1996. $591 \mathrm{c.}$

Кобзев 2009 - Кобзев А. И. Сань цзы цзин. В кн.: Духовная культура Китая: энциклопедия: в 5 т. Т. 5 : Наука, техническая и военная мысль, здравоохранение и образование. Титаренко М. Л. (ред.). М.: Восточная литература, 2009. С. 825-828.

Круглов 2004 - Круглов В. М. Русский язык в начале XVIII века: узус петровских переводчиков. СПб.: Наука, 2004. 102 c.

Мурзанова, Бобров, Петров 1956 - Мурзанова М.Н., Бобров Е. И., Петров В. А. Исторический очерк и обзор фондов рукописного отдела Библиотеки Академии наук. Вып. 1. Адрианова-Перетц В.П. (ред.). М.; Л.: Изд-во АН СССР, 1956. 483 с.

Сидихменов 2010 - Сидихменов В. Я. Китай: странищы прошлого. Смоленск: Русич, 2010. 544 с.

Скачков 1977 - Скачков П.Е. Очерки истории русского китаеведения. М.: Наука, 1977. 503 с.

Таранович 1945 - Таранович В. П. Иларион Россохин и его труды по китаеведению. В кн.: Советское востоковедение. Вып. ІІІ. Баранников А. П., Крачковский И. Ю., Петров А. А. (ред.). М.; Л.: Издво АН СССР, 1945. С. 225-241.

Чжан 2018 - Чжан Хунъянь. Переводы «Сань-Цзы-Цзин» и их влияние в России. Иностранные языки в высшей школе. 2018, 1(44): 93-98.

Югай 2006 - Югай В.Б. Феномен «Сань цзы цзина». В кн.: «Философии Восточно-Азиатского региона и современная ицвилизаиия», всероссийская конференция. Информационные материалы. Вып. 13 (Москва, 23-24 ноября 2004 г. и 23-24 мая 2005 г.). Ч. 1. М.: Институт Дальнего Востока, 2006. C. $138-144$.

Ли 2004 - 李良品 [Ли Лянпин]. 《三字经》的成书过程与作者归属考略 [К вопросу о процессе создания «Сань цзы цзин» и его авторе]. 社会科学家 [Социолог]. 2004, 5: 156-160. (Китайск.)

Ли 2008 - 李健明 [Ли Цзяньмин]. 《三字经》主要版本内容研究 [Изучение содержания главных версий «Сань цзы цзин»]. 学术研究 [Академические исследования]. 2008, 8: 125-129. (Китайск.)

У 2007 一伍宇星 [У Юйсин]. 《三字经》在俄国 [«Сань цзы цзин» в России]. 学术研究 [Академические исследования]. 2007, 8: 110-115. (Китайск.) 
Цай 2006 - 蔡鸿生 [Цай Хуншэн]. 俄罗斯馆纪事 (增订本) [Записи Русского посольского двора. 2-е изд., доп. и испр.]. 北京 [Пекин]: 中华书局 [Издательство «Чжунхуа»], 2006. 251 с. (Китайск.)

Чжао 2015 - 赵凤玲 [Чжао Фенглин]. 《三字经》的西译历程一兼谈中国文化走向世界的现实途径 [Процесс перевода «Сань цзы цзин» на иностранные языки и практический путь мирового распространения китайской культуры]. 文化学刊 [Культура]. 2015, 11: 132-138. (Китайск.)

Чжао 2014 - 赵彦春 [Чжао Янчунь]. 英韵三字经 [Сань изы изин в английском ритме]. 北京 [Пекин]: 光明日报出版社 [Изд-во «Гуанмин жибао»], 2014. 119 с. (Китайск.)

Статья поступила в редакцию 11 июля 2018 г. Статья рекомендована в печать 21 ноября 2018 г.

\section{Chen Shengnan}

Saint Petersburg State University,

7-9, Universitetskaya nab., St. Petersburg, 199034, Russia

727852429@qq.com

\section{On the first translation of Sanzijing into the Russian}

For citation: Chen Shengnan. On the first translation of Sanzijing into the Russian. Vestnik of Saint Petersburg University. Language and Literature. 2019, 16 (2): 320-332. https://doi.org/10.21638/ spbu09.2019.211 (In Russian)

Sanzijing or The Three Character Classic was one of the first books for school education in ancient China for hundreds of years. The book contains basic knowledge about Chinese culture, philosophy, geography, history, and the like. It is written in metrical prose: each line consists of three characters and every four lines form one stanza. The book Sanzijing was also important material for teaching Chinese to foreign missionaries who came to China after the $16^{\text {th }}$ century. In this article we compare two Russian translations of this book in two manuscripts in the Department of Manuscripts of the Library of the Academy of Sciences. These two are attributed by V. P. Taranovich and P. E. Skachkov to Illarion K. Rossokhin (1717-1761), a student of the second Russian Ecclesiastic Mission. A comparison of the two translations showed that the text in one manuscript was translated by Rosskhin, while another was translated by another person earlier. The earlier translation is likely to have been completed under Peter the Great: this is evidenced by features of the orthography, lexis, and grammar that were specific to this period. Further, the translations had different purposes: Rossokhin's translation contained explanations and was aimed at teaching Chinese, while the other was translated word by word and had no clear didactic purpose.

Keywords: Ilarion Rossokhin, Sanzijing, Russian translations of the XVIII century.

\section{References}

Галенович 2012 - Sanzijing or Troeslovie (Three Words Canon). Transl. from Chinese. Galenovich Iu. M. (transl., ed.). Moscow: SPSL, Russkaia panorama Publ., 2012. 296 p. (In Russian)

Григорьева 2004 - Grigor'eva T.M. Three centuries of Russian Orthography. Moscow: Elpis Publ., 2004. 456 p. (In Russian)

Живов 1996 - Zhivov V.M. Language and culture in Russia of the XVIII century. Moscow: Iazyki russkoi kul'tury Publ., 1996. 591 p. (In Russian)

Кобзев 2009 - Kobzev A. I. Sanzijing. In: Dukhovnaia kul'tura Kitaia: entsiklopediia: In 5 vols. Vol. 5. Titarenko M. L. (ed.). Moscow: Vostochnaia literatura Publ., 2009. P. 825-828. (In Russian)

Круглов 2004 - Kruglov V. M. Russian language at the beginning of the XVII century: the pattern of Peter's the Great translators. St. Petersburg: Nauka Publ., 2004. 102 p. (In Russian) 
Мурзанова, Бобров, Петров 1956 - Murzanova M.N., Bobrov E.I., Petrov V.A. Historical essay and review of the funds of the Manuscript Department of the Library of the Academy of Sciences. Vol.1. Adrianova-Peretts V.P. (ed.). Moscow; Leningrad: USSR Academy of Sciences Publ., 1956. 483 p. (In Russian)

Сидихменов 2010 - Sidikhmenov V.Ia. China: pages of the past. Smolensk: Rusich Publ., 2010. 544 p. (In Russian)

Скачков 1977 - Skachkov P. E. Essays on the history of Russian Chinese studies. Moscow: Nauka Publ., 1977. 503 p. (In Russian)

Таранович 1945 - Taranovich V.P. Ilarion Rasskhin and his works on Chinese studies. In: Sovetskoe vostokovedenie. Vol. III. Barannikov A. P., Krachkovskii I. Iu., Petrov A. A. (eds.). Moscow; Leningrad: USSR Academy of Sciences Publ., 1945. P. 225-241. (In Russian)

Чжан 2018 - Chzhan Khun"ian'. Translation of Sanzijing. Inostrannye iazyki v vysshei shkole. 2018, 1 (44): 93-98. (In Russian)

Югай 2006 - Iugai V. B. [Phenomenon Sanzijing]. In: "Filosofii Vostochno-Aziatskogo regiona i sovremennaia tsivilizatsiia”, All-Russian Conference: Proceedings. Issue 13: 'Filosofii Vostochno-Aziatskogo regiona i sovremennaia tsivilizatsiia": X and XI All-Russian Conferences (Moscow, November 23-24, 2004 and May 23-24, 2005). Part. 1. Moscow: Institute of the Far East Press, 2006. P. 138-144. (In Russian)

Ли 2004 - Li Liangping. [About the completion process and the author of "San tszy tszin"]. She hui ke xиe jia [Social scientist]. 2004, 5: 156-160. (In Chinese)

Ли 2008 - Li Jianming. [Study on the contents of the main versions of "Sanzijing"]. Хие shu yan jiu [Academic research]. 2008, 8: 125-129. (In Chinese)

У 2007 - Wu Yuxing. ["Sanzijing" in Russia]. Xue shu yan jiu [Academic research]. 2007, 8: 110-115. (In Chinese)

Цай 2006 - Cai Hongsheng. E luo si guan ji shi [Chronicle of Russian court]. Beijing: Zhonghua Book Company, 2006. 251 p. (In Chinese)

Чжао 2015 - Zhao Fengling. [The process of Western translation of "Sanzijing": The realistic way for Chinese culture to enter the world]. Wen hua xue kan [Journal of Cultural Studies]. 2015, 11: 132-138. (In Chinese)

Чжао 2014 - Zhao Yanchun. Ying yun san zi jing [“Sanzijing” on the English rhythm]. Beijing: Guangming Daily Press, 2014. 119 p. (In Chinese) 


\section{Corrigendum:}

Ван, И. (2019). Оценочная конструкция с элементом обоснования типа «Это мне не по плечу» в русском языке. Вестник Санкт-Петербургского университета. Язык и титература, 16 (1), 33-47. https://doi.org/10.21638/spbu09.2019.103

В списке литературы этой статьи источник

Гиро-Вебер 1996 - Гиро-Вебер М. Бисинхронный метод описания прилагательного в предикативной позиции в современном русском языке. В кн.: Теория функииональной грамматики: Качественность. Количественность. Бондаренко А. В. (ред.). СПб.: Наука, 1996. С. 65-79.

следует читать:

Гиро-Вебер 1996 - Гиро-Вебер М. Бисинхронный метод описания прилагательного в предикативной позиции в современном русском языке. В кн.: Теория функииональной грамматики: Качественность. Количественность. Бондарко А. В. (ред.). СПб.: Наука, 1996. С. 65-79. 